\title{
Review: What Makes Our Insects Sick?
}

\author{
Boucias, D.G. \& J.C. Pendland 1998: Principles of Insect Pathology. Kluwer Aca- \\ demic Publishers, Boston/Dordrecht/London. Pp. 537.
}

Most of us entomologists collect insects and some of us keep them for research and entertainment or may even culture them for a variety of purposes. The problem of sick insects, in other words "Insect Pathology", should therefore interest all of us. I myself, for instance, have often wondered why my caterpillars paled and then died despite an ample supply of food, or why my beetles suddenly succumbed or the stick insects in my terrarium grew weaker and weaker. Can the new book on the market "Principles of Insect Pathology" help answering questions like these? Unfortunately, it cannot.

The authors Drion G. Boucias and Jacquelyn C. Pendland (both not exactly household names in the field of insect pathology) tried to fill a gap in the entomological literature by writing a new textbook which, they claim "encompasses the general principles of insect pathology". In contrast to the older and still frequently cited volumes by Steinhaus (1949, 1963), Fuxa \& Tanada (1987) and Tanada and Kaya (1993), the authors of the new book attempted to include, whenever possible, discussions of homologous pathogens infecting vertebrate and plant hosts, but in my view they have not succeeded.

The book's title "Principles of Insect Pathology" promises more than it can keep. It covers in 5 sections viruses, bacteria, fungi, protozoa, and host defences, but there are no sections on gregarines, nematodes, nematomorphs like Gordius spp., ectoparasites like mites, etc. and in the section dealing with host defences, the current and exciting research on insect nociception and fever is ignored. Inconsistencies, so manifest throughout the pages of this book, already appear in the Preface where it says "The senior author acknowledges the friendship of..." ( $3^{\text {rd }}$ person singular), but continues "I would like to thank..." (1 $1^{\text {st }}$ person singular). Unimportant as this may seem, it is symptomatic for the entire book. The authors extend their gratitude "to Flora MacColl for doing the much of the typing..." (which nobody appears to have proofread, for even Boucias et al's own 1996 paper is cited as Pfanzenshutz-Natrichten on page 29 and PflanzenhutzNatrichten on page 286 , both versions, by the way, incorrect). And why mention the nationalities of some researchers ("...the Russian D. Ivanosky and the Dutchman M. Beijerinck..."), but fail to say where "...the pioneering work of A. Mayer..." was carried out? Inconsistencies throughout: chapters 1 and 2 begin with citations (by L. Thomas and R. Gallo, respectively), chapters 3 and 4 lack such citations and chapter 5 possesses one again ("Martians - dead-slain by the putrefactive and disease bacteria against which their systems were unprepared..." H.G. Wells, War of the Worlds, 1934).
What is the purpose of such citations, I ask myself.

In the absence of other new books on insect pathology on the market, students can try, of course, to extract some useful background information on some insect diseases from this book, but in the authors' own words "...use of this book as a framework rather than a definitive text is especially important... We hope...that the student will seek supplemental information on disease epidemiology... we believe that this text will serve as a general introductory reference book...". It is that last statement, however, that will really frustrate users of this book. How can anyone use this book as a reference book, when so many studies, referred to in the text by name of author(s) and year of publication, do not appear in the list of references at the ends of each chapter? The splitting of the references into 'General' and 'Specific', intended to facilitate a search, actually complicates it. The failure to include cited works in the references begins already on the first page of chapter 1: Schwenamber \& Gassner 1989, cited in the text, is nowhere to be found in the references. Or is it perhaps Schwemmler \& Gassner they mean? Finnegan 1989 (p. 104), Robertson \& Lampe 1995 (p. 105), Robertson 1995 (p. 106), Kim et al. 1995 (p. 108), Alstad \& Andow 1995 (p. 252, Goy \& Duesson 1990 (p. 252), these and many more are cited in the text, but not given in the references! Very frustrating for student and serious researcher alike, especial$1 y$ if they have paid US $\$ 250$.- or UKE 170.- (i.e. at least 1000 Finnish Mark!), which is what this $15.5 \times 24.2 \times 2.7 \mathrm{~cm}$ large book is supposed to cost (price information provided by Kluwer Academic Publishers).

Another really inexcusable omission is that none of the light- or electron micrographs contain scale bars or information in the legend about the magnifications used. Instead, one reads "columnar epithelium of a scarab larva". Do the authors not know that there are at least 40,000 different species of "scarab"? Or, another sample from the book, on p. 49 "Light micrograph of a hematoxylin-stained paraffin section of caterpillar tissue infected with a nuclear polyhedrosis virus...". What kind of caterpillar? How thick a paraffin section? Light micrograph of what magnification? How is an interested reader to guess the size of the illustrated "inclusions in nuclei"? And who knows the size (or instar) of the infected caterpillar? The lack of information on magnifications is such a serious oversight that it makes the micrographs of infected tissues, viruses, bacteria, spores, conidia, etc. almost meaningless. Somewhat annoying was also that the $\mathrm{Zy}$ gomycete insect fungus, known to most entomologists as Empusa muscae, appears not to have been mentioned, until the 
reader realizes that the authors prefer the name Entomophtora muscae. It should at least have been pointed out to the reader that the two names describe the same organism.

Some of the better parts of the book are spoiled by carelessness or simply inexperience on part of the authors. The chapter on microsporidia is typical. Even if these protozoans do not feature in the authors' own research, the two authors have put together some useful general remarks about this important group of invertebrate pathogens. However, quite apart from the by now familiar inaccurate citations (Canning 1986 on p. 401 becomes Canning 1988 in the general references), they do not focus on insect microsporidia, but in a "partial list of the Nosema species isolated from various host animals" include athymic mice, humans, and bryozoans. Having discovered microsporidia in the retinal tissue of the staphylinid beetle Creophilus erythrocephalus (Meyer-Rochow 1972), I would have been a lot more interested in a list of host insects. On p. 413 it is stated that the "...list of genera discussed in this section and their higher affiliated taxa are presented in Table 12-2." In that table the reader finds 10 genera, but they are not at all all being discussed in the section of the book dealing with microsporidia (as promised): only 4 genera are presented and discussed.

To ignore all the excellent work on microsporidia done in France, the work on insect viruses, bacteria, and patho- genic fungi in Australia, India, and Japan (to name but a few countries in which this line of research is strongly represented), casts a pretty poor light on the authors' overall awareness of what goes on in the world of insect pathology today. Ultimately, of course, students will have to be the judges as to whether this book is worth its money and destined to be a success or failure. Having shown it to some students, I know they did learn something from it, but I also know that this book will certainly not be a bestseller!

Fuxa, J.R., Tanada, Y. 1987: Epizootiology of Insect Diseases. - J. Wiley \& Sons, New York. 555 pp.

Meyer-Rochow, V.B. 1972: An intracellular microsporidian parasite from the compound eye of Creophilus erythrocephalus (Staphylinidae: Coleoptera). - Zeitschrift für Parasitenkunde 38: 174-182.

Steinhaus, E.A. 1949: Principles of Insect Pathology. McGraw Hill, New York. 757 pp.

Steinhaus, E.A. (ed.) 1963: Insect Pathology: Advanced Treatise (2 vols.). - Academic Press, New York.

Tanada, Y., Kaya, H. 1993: Insect Pathology. - Academic Press, New York. 666 pp.

V.B. Meyer-Rochow 